\title{
Fasad Museum Semarajaya Klungkung sebagai Tinggalan Arkeologi Kolonial
}

\author{
Komang Bagus Krishnayana Putra \\ Program Studi Arkeologi, Fakultas Ilmu Budaya, Universitas Udayana \\ [baguskrishna03@gmail.com] \\ *Corresponding Author
}

\begin{abstract}
This research highlight the architectural study for façade of Museum Semarajaya. The aims for this research was to acknowledge the form, architecture style, and cultural elements that influenced this façade. Based on this research, I attempted to explain these issues, like how the form and architectural style, and what are these cultural influences. In order to solve these issues, I used some analysis such as qualitative, stylistical, and morphological analyisis and also used Architectural, acculturation, and diffusion theory to develop the research analysis result interpretation. This façade can be classified into Dutch colonial architectural style as an eclecticism style, which has mixed style between colonial and Balinese traditional style. Based on the field observation, there have cultural influences. Such as Balinese influence, seen by its traditional ornaments at the base of this building, also colonial influence by usage of Dutch colonial architecture elements.
\end{abstract}

Keywords: Façade, Museum Semarajaya, Colonial Archaeology

\section{Latar Belakang}

Fasad adalah bagian depan dari sebuah seni bangunan atau arsitektur. Karena itu, berbicara tentang fasad, juga berarti berbicara tentang arsitektur. Pada masa penjajahan Belanda, Indonesia mengalami pengaruh Occidental (Barat) dalam berbagai segi kehidupan termasuk kebudayaan. Hal tersebut antara lain dapat dilihat dalam bentuk kota dan bangunan. Namun demikian tidak dapat dipungkiri bahwa para pengelola kota dan para arsitek Belanda tidak sedikit menerapkan konsep lokal atau tradisional dalam perencanaan dan pengembangan kota, permukiman, dan bangunan-bangunan. (Sumalyo, 1993: 3). Masuknya bangsa Asing ke Bali sekitar Tahun 1600 membawa pengaruh-pengaruh kebudayaan khususnya di bidang bangunan. Pengaruh-pengaruh Asing tersebut yang sangat kuat adalah dari bangsa Cina dan Belanda. Pengaruh Cina terungkap pada pemakaian ornamen berupa patra Cina dan memanfaatkan uang serta piring porselin pada bangunan, sedangkan pengaruh Belanda dan bangsa asing lainnya dapat dirasakan dengan lahirnya bentuk-bentuk bangunan Balai Loji, Balai Rum Kekantoran dan pemakaian patra Wulanda, patra Mesir sebagai ornamen (Kerthiyasa, 1984: 21). Hal ini menjadi acuan bagi pembangunan sekolah (sekarang museum) yang berada di Klungkung.

Museum Semarajaya terletak di dalam kawasan Kertha Gosa di Jalan Untung Surapati No.3, Kelurahan Semarapura Kelod, Kecamatan Klungkung, Kabupaten Klungkung, Provinsi Bali. Museum 
Semarajaya dibangun pada Gedung Bekas Sekolah MULO (Sekolah Menengah Jaman Belanda) dan bekas SMPN I Klungkung. Di dalam museum yang diresmikan pada 28 April 1992 ini dipamerkan barang-barang dari zaman prasejarah, benda-benda tinggalan perang puputan Klungkung, barang-barang perlengkapan upacara adat, sampai hasil dokumentasi keturunan raja-raja di Klungkung.

Fasad Museum Semarajaya Klungkung belum pernah diteliti terkait kajian arsitektur fasad-nya. Maka dari itu, perlu untuk dilakukan penelitian mengenai "Fasad Museum Semarajaya Klungkung sebagai Tinggalan Arkeologi Kolonial".

\section{Pokok Permasalahan}

Berdasarkan uraian di atas maka penulis dalam penelitian ini berusaha untuk memaparkan permasalahan sebagai berikut.

1. Bagaimana bentuk dan gaya arsitektur fasad Museum Semarajaya?

2. Unsur-unsur budaya apa saja yang mempengaruhi fasad Museum Semarajaya?

\section{Tujuan Penelitian}

Adapun tujuan-tujuan penelitian ini adalah sebagai berikut. 1) Untuk mengetahui bentuk dan gaya arsitektur terhadap fasad Museum Semarajaya. 2) Untuk mengetahui unsur-unsur budaya yang mempengaruhi fasad Museum Semarajaya.

\section{Metode Penelitian}

Metode penelitian yang digunakan adalah metode kualitatif. Metode kualitatif merupakan prosedur penelitian yang menghasilkan data deskriptif berupa katakata tertulis maupun lisan dari orang-orang dan perilaku yang diamati. Data yang dapat dijelaskan secara deskriptif dengan penyajian apa adanya sehingga data yang diperoleh tidak berbeda dengan keadaan lapangan (Museum Semarajaya). Berdasarkan hal ini, rancangan pokok pada penelitian ini dijelaskan dan dianalisis permasalahan yang telah diajukan, yaitu terkait dengan fasad Museum Semarajaya. Teknik pengumpulan data yang dapat dimanfaatkan adalah observasi, studi pustaka, dan wawancara dari informaninforman yang bersangkutan di lokasi penelitian yaitu Museum Semarajaya, Kota Semarapura, Kabupaten Klungkung.

Analisis yang digunakan dalam penelitian ini yaitu analisis kualitatif untuk mengolah dan menganalisis data-data yang terkumpul menjadi data yang sistematik, teratur, terstruktur dan mempunyai makna, selanjutnya analisis stilistik dilakukan dengan mengamati variabel-variabel yang berupa ragam hias, baik berupa ragam hias arsitektural maupun ragam hias dekoratif. Penelitian ini juga menggunakan analisis morfologi untuk mengamati variabelvariabel yang dapat dibagi menjadi tiga bagian, yaitu bagian kaki, tubuh, dan atap. Selain itu variabel ukuran, denah, arah hadap, dan ragam hias juga merupakan satuan pengamatan yang harus diperhatikan pula.

\section{Hasil dan Pembahasan}

Fasad Museum Semarajaya dapat dibagi sesuai permasalahan yang dibahas pada penelitian ini, yaitu bentuk, gaya arsitektur, dan unsur-unsur budaya yang mempengaruhi fasad Museum Semarajaya.

\section{a. Bentuk Arsitektur Fasad Museum Semarajaya}

Secara arsitektural, Fasad Museum Semarajaya memiliki bentuk yang khas. 
Bentuk Fasad Museum Semarajaya terdiri atas tiga bagian, antara lain bagian kaki, bagian badan, dan bagian atap.

Bagian kaki fasad Museum Semarajaya juga disebut dengan bebaturan memakai ragam hias lebih dominan daripada bagian tengah dan bagian atas fasad museum. Penempatan macam hiasan disesuaikan dengan tempat kehidupan dari bentuk yang dijadikan hiasan, misalnya kekarangan dan pepatraan. Karang gajah (Asti) dan karang batu di bawah, karang bunga dan karang simbar di tengah sedangkan karang goak di atas. Perlu diperhatikan keseimbangan antara luas bidang yang dihias dengan luas bidang terbuka. Hiasan yang terlalu sedikit terasa kesan kemiskinan sedangkan bidang-bidang yang penuh hiasan terasa nilai-nilai inflasi pada keseluruhannya. Bentuk-bentuk yang di karang sebagai hiasan tentunya hanya merupakan pendekatan dari bentuk asalnya (Gelebet, 1978: 133).

Adapun ragam hias yang digunakan pada bebaturan fasad Museum Semarajaya berikut ini.

1) Karang Goak adalah salah satu kekarangan yang disebut juga sebagai "karang manuk", karena mendekati bentuk paruh burung goak yang serupa pula dengan paruh ayam yang lengkung lancip dengan pipi, mata, dan beberapa bagian lainnya. Paruh goak atau paruh manuk hanya bagian atasnya, bagian bawah tidak. Hiasan karang goak memakai mata bulat, taring dan gigi runcing, yang tentunya tidak ada pada seekor goak atau manuk (Gelebet, 1978: 133). Di Museum Semarajaya, karang goak paling dominan berada di bebaturan bangunan fasad, yaitu berada di sekitar tangga timur, tangga utara (cripedoma), dan di samping balustrade timur terdapat dua karang goak disertai dengan karang simbar sebagai satu kesatuan objek. Selain terletak di cripedoma dan balustrade, terdapat dua karang goak di setiap tiang pilar tanpa karang simbar. Ada yang memiliki tiga karang goak, biasanya terletak di penghujung bangunan fasad.

2) Karang simbar merupakan wujud pendekatan dari tumbuh-tumbuhan yang mirip tanduk menjangan dengan daun terurai menjalar ke bawah yang keluar dari mulut goak. Karang simbar ini berada di bawah karang goak sebagai satu kesatuan objek. Di Museum Semarajaya, karang simbar ini ditempatkan di bebaturan bangunan fasad, yaitu tepat di bawah karang goak di sekitar tangga timur dan tangga utara (cripedoma).

3) Karang asti merupakan bentuk pendekatan dari bentuk gajah, ada gadingnya ada belalainya. Mata bulat gigi runcing tentunya bukan bentuk dari seekor gajah (Gelebet, 1978: 133). Di Museum Semarajaya, karang asti ditempatkan pada bebaturan bangunan fasad, khususnya di sekitar tangga timur dan tangga utara (cripedoma).

4) Karang tapel merupakan suatu kekarangan yang mempunyai bentuk pendekatan dari bentuk tapel. Ciri-ciri tapel yaitu bermata bulat, bergigi datar dengan taring runcing, hidung kedepan, dan lidah menjulur. Ornamen ini ditempatkan pada peralihan bidang di bagian tengah. Pada Museum Semarajaya, karang tapel ini ditempatkan di bebaturan bangunan, yaitu di sekitar tangga timur dan tangga utara serta ditempatkan di bawah tiang pilar bersama dengan sepasang atau tiga karang goak.

5) Karang sae adalah salah satu kekarangan yang merupakan pengaruh Tiongkok yang dikembangkan sesuai dengan bentuk-bentuk Boma sebagai hiasan tradisional. Bentuk karang sae 
menyerupai bentuk kelelawar, mata bulat, bertaring, gigi runcing dengan tangan lima jari berkuku runcing serupa kuku harimau, diperkenankan untuk bangunan-bangunan umum (Gelebet, 1978: 135). Karang sae dilengkapi dengan patra sari yang diasimilasikan dengan patra punggel, seakan keluar dari mulut dipegang oleh kedua tangannya melentur ke atas dan terurai ke bawah membentuk pola hiasan yang harmonis. Penempatan karang sae berada pada bidang atau bentuk-bentuk vertikal, terutama yang lengkap dengan bagian-bagian kepala, badan, dan kaki seperti pintu, kori atau Kori Agung yang lengkap dengan gelung agung di kepala. Karang sae kurang sesuai dengan bentuk atau bidang-bidang horisontal seperti lisplank, dinding memanjang, dan dinding serupa (Gelebet, 1978: 135). Karang sae yang terdapat di fasad Museum Semarajaya, penempatannya berada di bebaturan bangunan fasad. Hal ini terbilang unik karena penempatannya berada di bawah, bukan di atas pintu, kori, atau kori agung. Tepatnya di balustrade bangunan fasad. Khususnya di dinding balustrade utara.

6) Karang Bunga merupakan suatu jenis ragam patra hias yang berbentuk bunga dengan kelopak dan seberkas daun. Di Museum Semarajaya, karang bunga ini banyak ditempatkan di bebaturan bangunan fasad, yaitu berada paling bawah. Selain itu, karang bunga juga terletak di balustrade bangunan fasad seperti pada gambar di atas ini.

7) Pepatraan adalah suatu ragam hias tradisional Bali yang digambarkan dalam bentuk menjalar. Ornamen ini banyak terdapat pada bebaturan bangunan fasad Museum Semarajaya. Pepatraan ini merupakan hasil akulturasi antara unsur budaya Bali dengan unsur budaya asing seperti Cina dan Belanda serta unsur budaya asing lainnya. Menciptakan pepatraan yang beragam. Antara lain, Patra Wulanda, Patra Cina, Patra Mesir, Patra Bali, Patra Kakul, Patra Punggel, dan Patra Banci. Terdapat sejumlah pepatraan pada bebaturan fasad Museum Semarajaya. Seperti Patra Bali berada di tengah dikelilingi oleh Patra Mesir. Patra Bali memiliki bentuk bunga dengan tangkai mengelilingi bunga. Sedangkan Patra Mesir memiliki bentuk sulur-suluran kaku. Di bawah pepatraan yang telah disebutkan terdapat Patra Kakul yang memiliki bentuk bulat seperti siput pada umumnya. Pepatraan ini letaknya berada di fasad utara Museum Semarajaya. Terdapat juga pepatraan yang diketahui sebagai Patra Cina yang berada di tengah dikelilingi pula oleh Patra Mesir, serta Patra Kakul. Patra Cina memiliki bentuk bunga kembang yang besar maupun kecil. Pepatraan ini terletak di bawah balustrade timur bagian utara fasad Museum Semarajaya.

8) Cripedoma merupakan tangga penghubung dari bawah menuju ke serambi. Tangga naik ini menghubungkan halaman atau natah dengan bangunan museum. Ketinggian lantai dari natah kurang lebih 1 meter dan terdapat dua tangga akses untuk menuju ke dalam museum yang terletak di bagian utara dan timur (Eradiputra, 2014: 20). Di bagian railing tangga terdapat dua figur naga. Di samping masing-masing cripedoma, terdapat dua relief, yaitu relief Singa Ambara Raja, dan relief Nandi.

9) Relief Singa Pinggala merupakan suatu relief yang terdapat pada salah satu bagian samping cripedoma. Sedangkan Relief Lembu Nandaka merupakan suatu relief yang terdapat pada salah satu bagian samping cripedoma. Bentuk relief Nandi 
ini berbentuk kerbau mempunyai sepasang tanduk. Kedua Relief ini berhubungan dengan cerita Tantri Hyookas dan Tabanan, karena kedua versi tersebut menampilkan cerita mengenai persahabatan Singa Pinggala dan Lembu Nandaka (Sudiana, 2013: 38).

10) Figur Naga adalah salah satu figur yang terdapat pada cripedoma fasad Museum Semarajaya sebagai pengapit anak tangga (railing). Pada railing tangga fasad Museum Semarajaya, sepasang figur naga yang dimaksud di atas adalah naga Taksaka. Terdapat dua pasang pada tiap cripedoma, yaitu cripedoma timur dan cripedoma utara. Ciri-ciri figur naga Taksaka ini meliputi mahkota, mata bulat, gigi runcing, serta badan memanjang sampai ekor ke balustrade. Di depan cripedoma fasad timur, terdapat dua tokoh penjaga pintu, yaitu sepasang Arca Dwarapala. Arca Dwarapala digambarkan dengan wajah ugra (marah) dengan gigi taring, mata melotot, postur badan yang buncit, memakai jatamakuta (mahkota), dan membawa gada.

Secara struktural, pada bagian badan fasad Museum Semarajaya berada di atas bebaturan atau bagian kaki. Terdapat 8 ruangan, 6 diantaranya digunakan sebagai kelas. Terdapat koridor atau selasar pada bagian fasadnya. Pada bagian koridor atau selasar terdapat 2 serambi, masing-masing memiliki tangga. Pada kelas masingmasing terdapat 2 pasang jendela dan 1 pintu. Pada kelas yang sekarang difungsikan sebagai ruang alat-alat tradisional selain memiliki hal tersebut di atas terdapat sepasang pintu yang segaris dengan tangga timur. Pada bangunan fasad ini terdapat 32 tiang yang menghadap ke timur maupun utara, 4 diantaranya terdapat di serambi. Jarak setiap tiang pilar pada fasad museum ini berjajar sepanjang 250 meter pada koridor atau selasar bangunan fasad.

Adapun bagian-bagian fisik dari bagian badan bangunan fasad sebagai berikut.

1) Balustrade berfungsi sebagai pagar pembatas balkon, ataupun dek bangunan. Biasanya terbuat dari beton cor ataupun dari bahan metal (Eradiputra, 2014: 6). Balustrade ini letaknya berada pada fasad timur dan fasad utara Museum Semarajaya Klungkung. Bahan balustrade ini menurut pengamatan penulis terbuat dari batu bata. Balustrade ini juga memiliki ragam hias seperti pepatraan dan bagian badan dan ekor sepasang Naga Taksaka yang mengapit anak tangga cripedoma bangunan fasad.

2) Selasar pada fasad Museum Semarajaya fungsinya sebagai jalan sirkulasi barang dan juga orang menghubungkan antara fasad timur dengan fasad utara. Terdapat dua balkon atau teras pada kedua fasad tersebut. Selasar ini diapit oleh dinding bangunan fasad dan tiang pilar yang berjejeran.

3) Tiang Pilar merupakan kolom vertikal yang terbuat dari batuan, kayu, atau metal yang berfungsi sebagai penopang beban atap secara struktural atau sebagai hiasan secara estetika. Tiang Pilar pada fasad Museum Semarajaya ini berjumlah 32 tiang berjejeran pada bagian fasad Museum Semarajaya menopang beban atap di atasnya. Dilihat dari bentuknya tiang pilar tersebut berbentuk balok dengan bagian bawah membesar dan bagian atas terlihat seperti berlipat menggunakan ornamen bernuansa Bali. Tiang ini juga memiliki pengaruh Yunani dengan tiga gaya seperti Doric, Ionic, dan Corinthian (Tomory, 1989: 300). Tiang pilar fasad ini gayanya berbeda, karena memakai elemen-elemen lokal, khususnya Bali.

4) Fitur-fitur lain yang terdapat pada fasad 
Museum Semarajaya pada bagian badan yaitu, entrance (pintu masuk) dengan dua daun pintu yang berjumlah satu unit pada fasad timur, dan jendela besar berbingkai kayu yang terdapat pada setiap kelas di Museum Semarajaya.

Bagian atap fasad Museum Semarajaya dari tampak atas berbentuk huruf L, kecuali bangunan baru di bagian barat yang merupakan Kantor Disbudpora Klungkung. Atapnya berbentuk limasan. Pada kedua fasad atapnya berbentuk gevel. Overstack atap pada gevel ini memakai kayu jatipada tampak bawah.

Gevel atau disebut dengan Gable merupakan suatu atap yang berbentuk pelana dengan bidang vertikal segitiga sama kaki. Gevel ini terdapat pada bagian atap fasad timur maupun fasad utara Museum Semarajaya. Gevel pada Museum Semarajaya menggunakan genteng sebagai ciri khasnya tersendiri, karena bangunan kolonial secara biasa menggunakan beton.

Gevel pada fasad timur ini memiliki pepatraan berbentuk segitiga dan memiliki papan nama sesuai dengan nama museumnya. Sedangkan pada gevel pada fasad utara ini memiliki pepatraan berbentuk segitiga juga, tetapi tidak terlihat menggunakan papan nama seperti pada gevel timur.

\section{b. Gaya dan Unsur-unsur Budaya yang Mempengaruhi Fasad Museum Semarajaya}

Museum Semarajaya adalah bangunan museum dimana bangunan ini merupakan hasil akulturasi kedua gaya arsitektur, yakni gaya arsitektur Bali dan gaya arsitektur Kolonial. Bangunan ini juga merupakan sebuah hasil difusi dari budaya kolonial dan budaya Bali menjadi satu kesatuan kebudayaan yang unik. Hal ini dapat dilihat dari tritisan atap (overstack) yang lebar. Selain itu juga terdapat penggunaan konsep Tri Angga pada bangunan, penggunaan ornamen hias khas Bali, serta bukaan-bukaan bangunan yang lebar dan dalam jumlah yang banyak (Eradiputra, 2014: 11). Adapun penjelasannya sebagai berikut.

1) Konsep Tri Angga adalah tata nilai yang membagikan kehidupan fisik dalam tiga bagian hierarki. Konsep Tri Angga ini dalam kehidupan sehari-hari diproyeksikan dalam setiap wujud fisik arsitektur, teritorial perumahan, teritorial desa dan teritorial kawasan. Konsep Tri Angga ini menyangkut pada wujud fisik arsitektur tradisional Bali.

2) Gaya dan pengaruh unsur Budaya Bali pada bangunan Museum Semarajaya dapat dilihat dari penggunaan konsep-konsep yang terpatri pada Arsitektur Tradisional Bali, khususnya konsep Tri Angga, dan elemen-elemen Arsitektur Tradisional Bali seperti pemakaian ragam hias tradisional yang terdapat pada bangunan tersebut. Pemakaian ragam hias ini sangat dominan pada bagian kaki (bebaturan) bangunan fasad Museum Semarajaya. Terdapat beberapa ragam hias seperti kekarangan, pepatraan, arca, serta ragam hias lainnya yang menghiasi bagian kaki ini, misalnya relief Tantri. Pengaruh unsur Budaya Bali terlihat pada bentuk fisik bangunan fasad, di bebaturan bangunan banyak ditemukan ragam hias tradisional Bali, ada beberapa pengaruh unsur ini seperti pemakaian ragam hias tradisional pada ventilasi udara, pemakaian pepatraan pada balustrade, serta pemakaian ornamen hias pada kolom yang menyatu dengan dinding. Pada bagian atas terlihat sedikit pemakaian ornamen hias karena pada bagian atap telah direnovasi pada tahun 1992, kecuali pada bagian gevel atapnya memiliki ragam hias 
seperti pepatraan yang membentuk segitiga sama kaki.

3) Gaya dan pengaruh unsur budaya kolonial pada fasad Museum Semarajaya mengikuti gaya arsitektur eklektisisme, di mana gaya arsitektur ini memiliki perpaduan antara Indische Empire Style dengan Khas Belanda. Indische Empire Style berakar pada arsitektur Bali dengan serambi depan pada fasad timur dan fasad utara sebagai respon pada kondisi iklim setempat. Selain itu, atap bangunan ini menggunakan atap limasan. Hanya saja kolom-kolomnya berbentuk segiempat dengan bagian bawahnya mempunyai ornamen hias kekarangan. Motif-motif lokal digunakan pada suatu bangunan. Gaya arsitektur Khas Belanda terlihat pada bentuk atap gevel dengan pediment tanpa dormer pada fasad timur dan fasad utara, hanya saja bangunan ini tidak memiliki menara. Sehingga, gaya eklektisisme pada bangunan ini menggunakan elemen-elemen berbagai gaya secara bebas, khususnya memadukan gaya arsitektur tradisional Bali ke gaya arsitektur kolonial. Museum Semarajaya memiliki elemen-elemen bangunan arsitektur kolonial. Terdapat dua gevel yang menghadap timur dan utara, sejumlah ragam hias pada tubuh bangunan (kekarangan-pepatraan), dan dua balustrade timur dan utara. Elemen-elemen yang lain seperti cripedoma, jendela dengan dua daun pintu, sejumlah tiang pilar, dan entrance dengan dua daun pintu juga tampak pada bangunan fasad tersebut. Pengaruh unsur budaya kolonial ini berkembang karena kebijakan desentralisasi tahun 1903 dan berkembang secara signifikan setelah Belanda menguasai Bali setelah perang Puputan Klungkung pada tahun 1908. Museum Semarajaya merupakan salah satu bangunan yang memiliki akulturasi antara unsur budaya Bali dengan unsur budaya kolonial berkat kebijakan desentralisasi yang telah disahkan pada tahun 1903. Di mana, hasil unsur budaya kolonial ini terlihat pada gaya bangunan museumnya, sebagai contoh gaya Indische Empire Style. Hal ini dapat diamati dari elemen-elemen bangunannya, misalnya gevel, balustrade, tiang pilar berjejeran, cripedoma, serta ragam hias pada bangunan tersebut.

\section{Simpulan}

Berdasarkan hasil penelitian yang telah diuraikan dalam bab-bab sebelumnya, penulis dapat menyampaikan simpulan sebagai berikut.

1) Dilihat dari bentuk dan arsitekturnya, fasad Museum Semarajaya memiliki bentuk yang terdiri atas tiga bagian, yaitu bagian kaki, bagian badan, dan bagian atap. Pada bagian kaki, terdapat banyak ragam hias tradisional Bali yang digunakan, serta memiliki cripedoma. Pada bagian tengah, terdapat banyak struktur seperti balustrade, selasar, tiang pilar, dan seterusnya. Pada bagian atap, terdapat dua gevel. 2) Dilihat dari gaya dan pengaruh unsur-unsur budaya pada fasad Museum Semarajaya, Museum Semarajaya Klungkung merupakan hasil akulturasi dari perkembangan gaya arsitektur eklektisisme pasca perang Puputan Klungkung tahun 1908 pada era tahun 1910 hingga tahun 1925. Hal ini disebabkan oleh kebijakan desentralisasi yang disahkan pada tahun 1903. Gaya Arsitektur Kolonial Belanda merupakan gabungan antara gaya Indische Empire Style dan Khas Belanda yang cukup berperan penting pada struktur bangunan, interior, dan eksterior bangunan khususnya fasad Museum Semarajaya, serta ragam hias pada bangunan fasad tersebut. Sedangkan Gaya Arsitektur Bali 
memiliki konsepsi-konsepsi tradisional Bali seperti konsep Tri Angga serta arah hadap atau orientasi arah. Difusi antara unsur budaya Bali dan unsur budaya Kolonial pada bangunan Museum Semarajaya menjadi contoh bangunan Indo-Eropa yang cukup berhasil dari banyaknya bangunan kolonial lain yang bergaya sama.

\section{Saran}

Kondisi Museum Semarajaya Klungkung kini jauh dari baik, terutama dari segi pemeliharaan. Bangunan yang sebelumnya difungsikan sebagai sekolah MULO dan umur bangunan yang sudah mencapai umur 97 tahun, tetap mendapat perawatan tidak hanya pada fisik bangunannya saja. Lingkungan di sekitar Museum Semarajaya juga perlu diperhatikan, agar nilai kultural dan nilai sejarah tetap dipertahankan.

Selain dari segi perawatan bangunan museum ini, juga dari segi sejarah perlu diketahui lebih lanjut karena museum ini pernah digunakan sebagai sekolah MULO. Diharapkan untuk penelitian lebih lanjut mengenai bangunan Museum Semarajaya ini lebih ke permasalahan sejarah sekolah MULO yang lebih rinci dari dibangunnya sampai dengan peralihan dari sekolah sebagai Museum Semarajaya, serta permasalahan konservasi dan perawatan terhadap bangunan museum ini. Dengan adanya Undang-undang No. 11 Tahun 2010 tentang Cagar Budaya ini, pemerintah pusat maupun pemprov dan pemkab telah banyak membantu usaha pemeliharaan serta pelestarian Museum Semarajaya. Diharapkan Pemerintah Pusat maupun setempat melalui Disbudpora lebih cepat dalam memberikan penanganan bangunanbangunan kolonial di Kabupaten Klungkung maupun Provinsi Bali yang memang terhitung banyak.

\section{Daftar Pustaka}

Eradiputra, Dwi Adintya. 2014. "Peran dan Pengaruh Arsitektur Kolonial pada Museum Semarajaya di Klungkung”. Artikel. Denpasar: Fakultas Teknik Universitas Udayana

Gelebet, I Nyoman. 1978. Arsitektur Tradisionil Bali: Dalam Rangka Pengembangan Kepariwisataan. Denpasar: Fakultas Teknik Universitas Udayana

Kerthiyasa, I Made. 1984. "Rumusan Arsitektur Bali”. Rumusan. Denpasar: Hasil Sabha Arsitektur Bali

Sudiana, I Putu Yogi. 2013. "Relief Tantri di Pertapaan Gunung Kawi Bebitra Desa Bitera, Gianyar". Skripsi. Denpasar: Program Studi Arkeologi Fakultas Sastra dan Budaya Universitas Udayana.

Sumalyo, Yulianto. 1993. Arsitektur Kolonial Belanda di Indonesia. Yogyakarta: GajahMada University Press

Tomory, Edith. 1989. A History of Fine Arts in India and The West. New Delhi: Orient Longman PVT. Limited 